\title{
Simultaneous bilateral posterior ischemic optic neuropathy secondary to giant cell arteritis: a case presentation and review of the literature
}

\author{
Anas Mohammad Albarrak ${ }^{1 *}$ (D) Yousef Mohammad ${ }^{2}$, Sajjad Hussain ${ }^{3}$, Sufia Husain ${ }^{4}$ and Taim Muayqil ${ }^{5}$
}

\begin{abstract}
Background: This report highlights a rare case of simultaneous bilateral blindness due to posterior ischemic optic neuropathy. Typically, ophthalmic involvement in giant cell arteritis is monocular or sequential ischemia of the anterior portion of the optic nerve, and less frequently simultaneous.

Case presentation: An 80-year-old Saudi male came with a history of simultaneous bilateral vision loss 5 days prior to presentation. The exam showed dilated non-reactive pupils, no light perception in both eyes, and normal fundus exam. C-reactive protein and erythrocyte sedimentation rate levels were high Magnetic resonance imaging and magnetic resonance angiography of the brain showed a right posterior optic nerve lesion and absence of flow in both ophthalmic arteries respectively. A left temporal artery biopsy confirmed giant cell arteritis.

Conclusion: The presentation of GCA can be atypical and patients may present with simultaneous blindness. Bilateral simultaneous PION does not exclusively occur in a post surgical setting, emphasizing the importance of decreasing the threshold of suspicion of similar cases to avoid further neurological complications.
\end{abstract}

Keywords: Giant cell arteritis, Blindness, Headache, Posterior ischemic optic neuropathy, Neuro-ophthalmology

\section{Background}

Giant cell (temporal) arteritis (GCA) is a chronic vasculitis of large and medium-sized vessels, which can affect individuals over 50 years of age [1] and is the most common systemic vasculitis [2]. Typically, patients may present with a new headache, jaw claudication and/or monocular vision loss [3]. In comparison to anterior ischemic optic neuropathy (AION), posterior ischemic optic neuropathy (PION) is an uncommon form of optic nerve ischemia that can occur secondarily to GCA [4]. Here, we describe an elderly patient who presented with simultaneous bilateral loss of vision due to posterior ischemic optic neuropathies and biopsy proven GCA. This case outlines the importance of rapid recognition of

\footnotetext{
*Correspondence: Dr.albarrak@gmail.com

${ }^{1}$ Department of Internal Medicine, College of Medicine, Prince Sattam Bin Abdulaziz University, Alkharj, Saudi Arabia

Full list of author information is available at the end of the article
}

GCA in the setting of an uncommon presentation as early management can prevent devastating and irreversible complications.

\section{Case report}

We report a case of an 80-year old hypertensive and diabetic Saudi male referred to our center after developing sudden bilateral painless visual loss five days earlier. There was a history of a bilateral temporal headache that had started a year earlier. The headache was more prominent on the left side, mild to moderate in severity, and stabbing in nature. It used to occur on average once a week and would spontaneously resolve over several seconds. However, the frequency had increased in the months preceding visual loss, occurring almost daily. There was no report of any previous episodes of diplopia, transient visual loss, jaw claudication, myalgia, constitutional symptoms, motor or sensory symptoms.

(c) The Author(s). 2018 Open Access This article is distributed under the terms of the Creative Commons Attribution 4.0 International License (http://creativecommons.org/licenses/by/4.0/), which permits unrestricted use, distribution, and reproduction in any medium, provided you give appropriate credit to the original author(s) and the source, provide a link to the Creative Commons license, and indicate if changes were made. The Creative Commons Public Domain Dedication waiver (http://creativecommons.org/publicdomain/zero/1.0/) applies to the data made available in this article, unless otherwise stated. 
Examination showed normal blood pressure, heart rate, and temperature. He was unable to perceive light in both eyes, and the pupils were bilaterally dilated, seven millimeters each, with no reaction to light. Fundoscopy showed normal appearing discs and retina. Ocular movements were full. The motor, sensory and coordination examination was normal. The C-reactive protein (CRP) upon admission was $132 \mathrm{mg} / \mathrm{L}$ and the erythrocyte sedimentation rate (ESR) was $40 \mathrm{~mm} / \mathrm{hr}$. A magnetic resonance imaging (MRI) of the brain was done (Fig. 1) and it showed a lesion in right optic nerve suggesting acute ischemia. The ophthalmic arteries were not visualized bilaterally by contrast magnetic resonance angiography (MRA) (Fig. 2). The clinical impression was of a bilateral Posterior Ischemic Optic Neuropathy (PION) due to giant cell arteritis (GCA).

The patient was started on intravenous Methylprednisolone $1000 \mathrm{mg}$ for five days then shifted to daily prednisolone $60 \mathrm{mg}$ orally. The vision did not improve but the headache improved significantly after a few days. A $2 \mathrm{~cm}$ segment of the left temporal artery was biopsied and the pathological findings confirmed giant cell arteritis (Fig. 3).

\section{Discussion}

Here we present a patient of Arab ethnicity who developed bilateral blindness after suffering from a simultaneous onset bilateral PION and a biopsy proven GCA. GCA is a granulomatous, medium to large vessel, inflammatory disease that can have devastating ischemic consequences to the eye $[5,6]$. It is considered a relatively unusual occurrence in Arabs [7] and is more commonly encountered in Caucasian ethnicity [8]. Its incidence is most marked among white individuals of Scandinavian descent $[9,10]$, with one large Norwegian study finding an increasing incidence between 1972 and 1992 that subsequently plateaued. Women are more likely to be affected than men and the typical patient is in the 8th decade of life $[5,9]$. The typical symptoms of GCA include headache, scalp tenderness, jaw claudication, and loss of vision [3]. Headache is a common symptom in GCA and occurs in more than two-thirds of patients [11]. Visual impairments of varying degrees occur in one or both eyes in about 25 to $50 \%$ of GCA patients [4, 12, 13]. PION from GCA is uncommon (Table 1), the visual loss is most

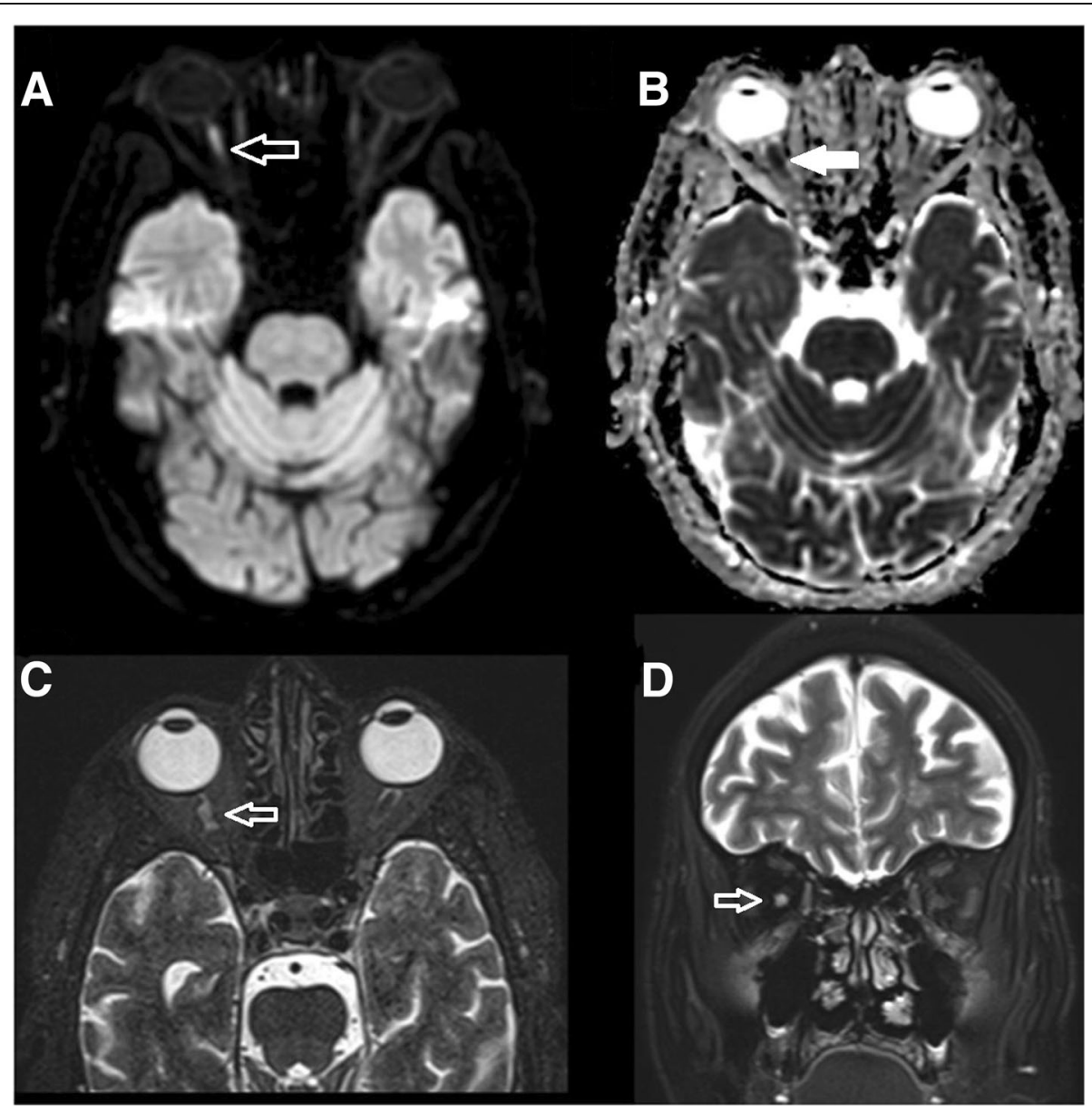

Fig. 1 a Axial diffusion weighted images. b ADC maps, c high resolution T2 weighted images and $\mathbf{d}$ coronal T2 weighted images. Arrows showing true diffusion restriction in the right optic nerve with $\mathrm{T} 2$ signal hyperintensity 


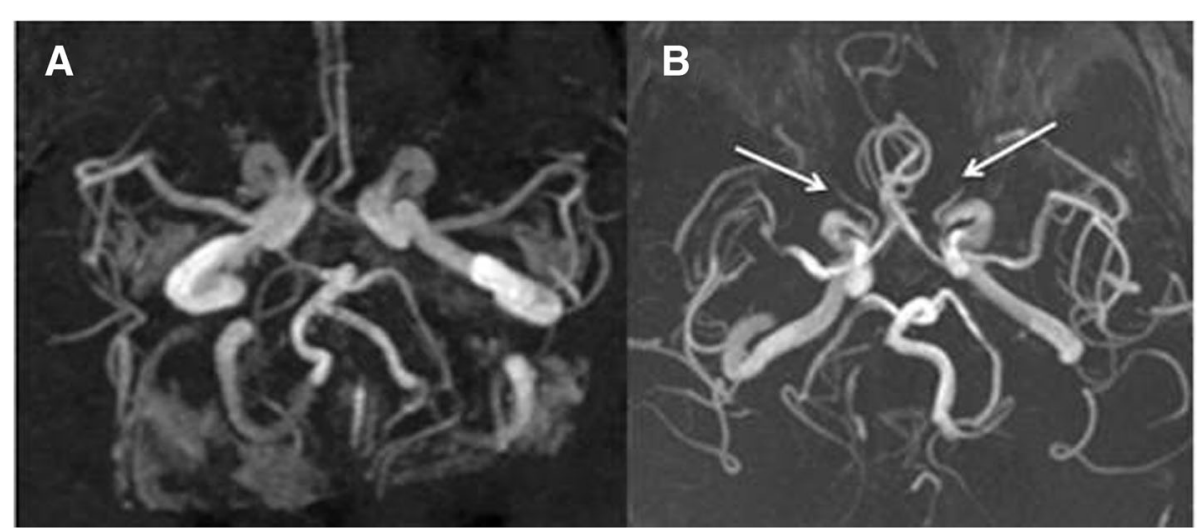

Fig. 2 MRA of the patient (a) versus a normal individual (b) with arrows indicating severe narrowing in ophthalmic arteries in the patient bilaterally

frequently the result of anterior ischemic optic neuropathies (AION), followed by central or branch retinal arterial occlusions $[4,8,14]$. In a prospective series of 170 patients with GCA, AION occurred in $81.2 \%$ of ocular ischemic cases, while PION occurred unilaterally in $5.9 \%$ and bilaterally in one patient [4]. Approximately $10 \%$ of visual impairment was from CRAO [4]. PION results from ischemia involving the retrobulbar part of the optic nerve [4], and is classified by etiology as non-arteritic, arteritic or surgical (perioperative) [4]. Typically, PION presents with monocular visual loss when non-arteritic and sequential visual loss when arteritic. Simultaneous bilateral visual loss is usually encountered in the perioperative type of PION [15] where perfusion abnormalities to
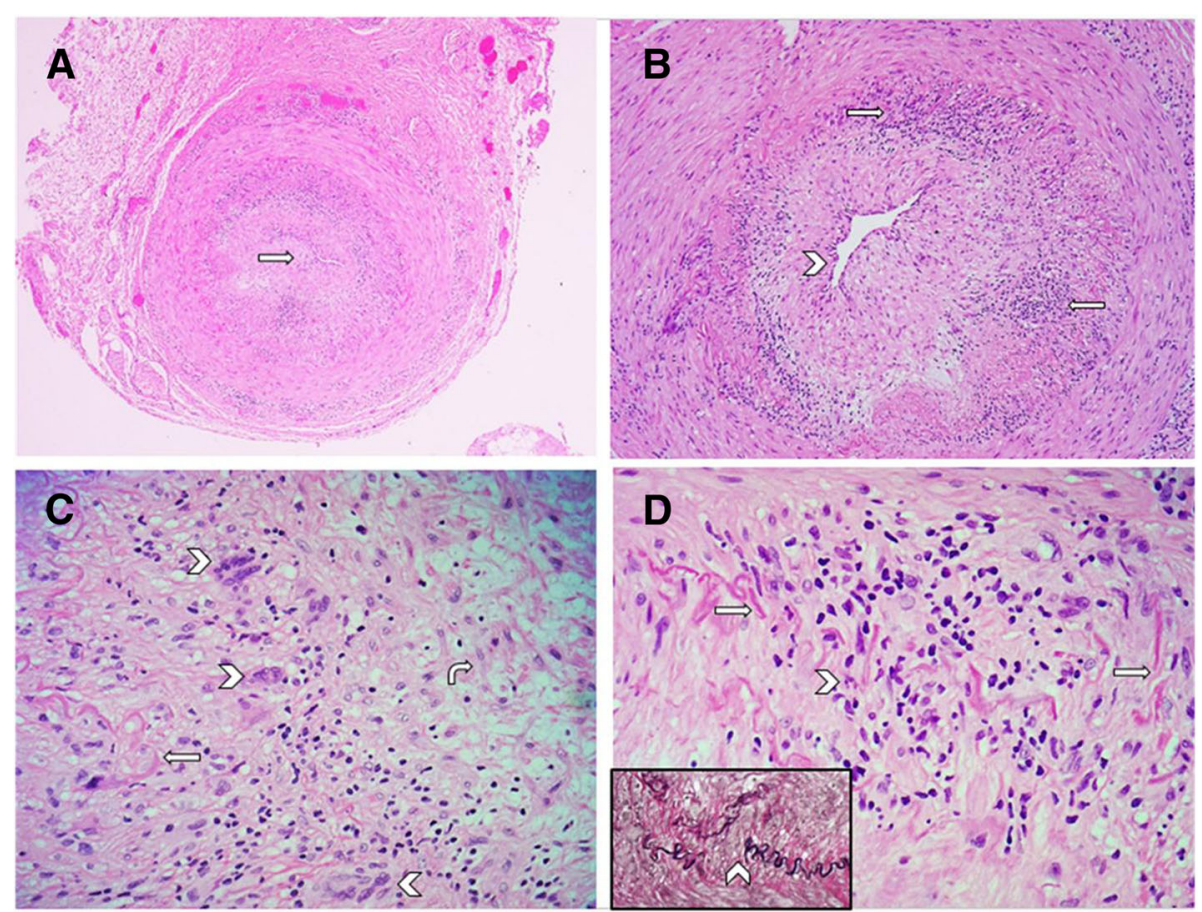

Fig. 3 Photomicrograph of a cross section of temporal artery shows (a) almost total occlusion of the vascular lumen (arrow) due to fibrointimal proliferation and arteritis (Hematoxylin and eosin stain; original magnification $\times 100$.). $\mathbf{b}$ Infiltration of the arterial intima and media by patchy moderately dense lymphohistiocytic inflammatory cells (arrows). The arterial lumen is reduced to a narrow slit-like channel (arrowhead)(Hematoxylin and eosin stain; original magnification $\times 200$.) $\mathbf{c}$ High magnification shows mononuclear inflammatory cell infiltrate mixed with scattered multinucleated giant cells (arrowhead) in the vessel wall. Fragmentation of the internal elastic lamina (arrow) and fibrointimal proliferation and edema (curved arrow) of the arterial intima is also shown (Hematoxylin and eosin stain; original magnification $\times 400$.) $\mathbf{d}$ High magnification shows a lymphohistiocytic inflammatory cell infiltrate (arrowhead) destroying and disrupting the internal elastic lamina (arrow). (Hematoxylin and eosin stain; original magnification $\times 400$.) Inset: shows elastic tissue stain highlighting the fragmented internal elastic lamina (arrowhead). (Elastic Van Gieson stain; original magnification $\times 400$ 
Table 1 Reports of posterior ischemic optic neuropathy secondary to giant cell arteritis

\begin{tabular}{|c|c|c|c|}
\hline & Number of patients & Number of cases & Clinical details \\
\hline Liozon et al. 2001[12] & $\begin{array}{l}174 \text { GCA } \\
147 \text { Biopsy proven GCA } \\
48 \text { Ophthalmic GCA }\end{array}$ & 2 (PION) & Both described as bilateral and recovered \\
\hline Hayreh et al. 1998 [4] & $\begin{array}{l}170 \text { Biopsy proven GCA } \\
85 \text { Ophthalmic GCA }\end{array}$ & $6(\mathrm{PION})$ & One described as Bilateral \\
\hline Garrity et al. 2017 [8] & 32 Biopsy proven ophthalmic GCA & $2(\mathrm{PION})$ & African American cohort \\
\hline Danesh-Meyer et al. 2005 [21] & 34 Biopsy proven ophthalmic GCA & $2(\mathrm{PION})$ & $\begin{array}{l}\text { One had PION on one side and AION on the other } \\
\text { side that was described as bilateral at presentation }\end{array}$ \\
\hline Liu et al. 1994 [22] & 45 biopsy proven ophthalmic GCA & $2(\mathrm{PION})$ & $\begin{array}{l}\text { One had PION on one side and AION on the other side } \\
\text { that was simultaneous onset }\end{array}$ \\
\hline Aiello et al. 1993 [23] & $\begin{array}{l}327 \text { GCA } \\
245 \text { Ophthalmic diagnosis } \\
204 \text { biopsy proven }\end{array}$ & 1 (PION) & \\
\hline Chaudhry et al. 2007 [7] & $\begin{array}{l}102 \text { Suspected ophthalmic GCA } \\
7 \text { biopsy proven }\end{array}$ & 1 (PION) & \\
\hline Sadda et al. 2001[15] & $72 \mathrm{PION}$ patients & 6 (Arteritic) & None simultaneous due to arteritis \\
\hline Hayreh 2004 [17] & $43 \mathrm{PION}$ patients & 12 (Arteritic) & \\
\hline
\end{tabular}

the eyes occur [16]. In contrast to AION, the optic disc examination is normal in the acute setting of PION, with the development of optic atrophy on follow up assessments appearing about 6 weeks after the event [17]. Findings on MRI are either normal or show hyper-intense signals on diffusion restricted images, while enhancement of the optic nerve with contrast can be seen in arteritic ischemic optic neuropathies [18].

The current patient presented with a history of headache for one year that culminated in bilateral visual loss from optic nerve ischemia. The differential diagnosis for a presentation of acute optic neuropathy with headache includes arteritic ischemic optic neuropathy, infections (cat-scratch, syphilis), inflammatory (para-infectious, multiple sclerosis, systemic autoimmune, paraneoplastic, and sarcoidosis). GCA in the current scenario presented fairly typically, readily distinguishing it from other conditions. The ESR and CRP were high which suggested an inflammatory process and abnormal signals were seen on the MRI suggesting infarction.

Simultaneous and sudden complete blindness of both eyes due to PION is an unusual presentation in GCA. Bilateral visual loss is usually due to the sequential onset of AION, CRAO, or PION in any combination $[4,15]$. One cohort that looked at a small subgroup of simultaneous onset bilateral ischemic optic neuropathies found examination findings of different ages in each eye, raising the possibility that patients may not become aware of visual loss until it involves the other eye [4]. Thus, an important consideration in the current case is defining how simultaneous was the onset. Our patient witnessed the visual loss occur while he was awake, and was found to have symmetrical exam findings when assessed at the referring center on the day of onset, and again at our center 5 days later with no clear disc abnormalities. There was diffusion restriction involving the right optic nerve with absence of both ophthalmic arteries by MRA. It was not surprising to find asymmetrical findings on MRI as PION changes may not always seen on MRI [19], and our patient did not have imaging done until one week after the event reducing the possibility of witnessing acute changes. Asymmetry in the observed MRI signals of bilateral simultaneous onset post surgical PION have also been described [20].

\section{Conclusions}

In this report we presented a patient who was clinically and histologically diagnosed as GCA. IV steroids were started upon his arrival five days from symptom onset, with dramatic improvement in headache, however, no improvement in vision occurred as is the case with optic nerve ischemia secondary to GCA [21]. Given the yearlong history of headache, this case emphasizes the importance of early recognition of headache disorders among elderly; the threshold of suspecting GCA in elderly patients should be very low. This case highlights a rarely identified ocular presentation of GCA, it is important to identify this early in order to start treatment to avoid devastating and potentially permanent ocular or systemic complication. When bilateral PION occurs simultaneously in a non-surgical setting in an older individual, then the possibility of GCA as an etiology should be considered high.

\section{Abbreviations}

AION: Anterior ischemic optic neuropathy; CRP: C-reactive protein;

ESR: Erythrocyte sedimentation rate; GCA: Giant cell arteritis; MRI: Magnetic resonance imaging; MRA: Magnetic resonance angiography; PION: Posterior ischemic optic neuropathy 


\section{Acknowledgements}

The authors thank the patient and his son for their collaboration.

\section{Funding}

No targeted funding reported.

\section{Availability of data and materials}

The datasets used and/or analysed during the current study are available from the corresponding author on reasonable request.

\section{Authors' contributions}

AA and TM acquisition of data, analysis and interpretation, manuscript concept and design; YM critical revision of the manuscript for important intellectual content and study supervision. $\mathrm{SH}$ and $\mathrm{FH}$ analysis and interpretation of data. All authors read and approved the final manuscript.

\section{Ethics approval and consent to participate}

Not applicable

\section{Consent for publication}

Written informed consent was obtained from the patient for publication of this case report and any accompanying images. A copy of the consent form is available for review by the Editor of this journal.

\section{Competing interests}

The authors declare that they have no competing interests.

\section{Publisher's Note}

Springer Nature remains neutral with regard to jurisdictional claims in published maps and institutional affiliations.

\section{Author details}

${ }^{1}$ Department of Internal Medicine, College of Medicine, Prince Sattam Bin Abdulaziz University, Alkharj, Saudi Arabia. ${ }^{2}$ Department of Internal Medicine, Neurology division, King Khalid University Hospital, Riyadh, Saudi Arabia. ${ }^{3}$ Department of Medical Imaging, King Saud University / King Khalid University Hospital, Riyadh, Saudi Arabia. ${ }^{4}$ Department of Pathology and Laboratory Medicine, King Khalid University Hospital, College of Medicine, King Saud University, Riyadh, Saudi Arabia. ${ }^{5}$ Neurology division, Department of Medicine, College of Medicine, King Saud University, Riyadh, Saudi Arabia.

Received: 1 August 2018 Accepted: 4 December 2018

Published online: 12 December 2018

\section{References}

1. Dejaco C, Brouwer E, Mason JC, Buttgereit F, Matteson EL, Dasgupta B. Giant cell arteritis and polymyalgia rheumatica: current challenges and opportunities. Nat Rev. Rheumatol. 2017;13(10):578-92.

2. Gonzalez-Gay MA, Garcia-Porrua C. Systemic vasculitis in adults in northwestern Spain, 1988-1997. Clinical and epidemiologic aspects. Medicine (Baltimore). 1999;78(5):292-308.

3. Salvarani C, Pipitone N, Versari A, Hunder GG. Clinical features of polymyalgia rheumatica and giant cell arteritis. Nat Rev. Rheumatol. 2012;8(9):509-21.

4. Hayreh SS, Podhajsky PA, Zimmerman B. Ocular manifestations of giant cell arteritis. Am J Ophthalmol. 1998;125(4):509-20.

5. De Smit E, O'Sullivan E, Mackey DA, Hewitt AW. Giant cell arteritis: ophthalmic manifestations of a systemic disease. Graefe's Arch Clin Exp Ophthalmol. 2016; 254(12):2291-306 Available from: https:/doi.org/10.1007/s00417-016-3434-7.

6. Vodopivec I, Rizzo JF. Ophthalmic manifestations of giant cell arteritis. Rheumatol (United Kingdom). 2018:57(May):i63-ii72.

7. Chaudhry IA, Shamsi FA, Elzaridi E, Arat YO, Bosley TM, Riley FC. Epidemiology of giant-cell arteritis in an Arab population: a 22-year study. Br J Ophthalmol. 2007;91(6):715-8.

8. Garrity ST, Pistilli M, Vaphiades MS, Richards NQ, Subramanian PS, Rosa PR, et al. Ophthalmic presentation of giant cell arteritis in African-Americans. Eye 2017;31(1):113-8. Available from: https://doi.org/10.1038/eye.2016.199

9. Brekke LK, Diamantopoulos AP, Fevang B-T, ABmus J, Esperø E, Gjesdal CG Incidence of giant cell arteritis in Western Norway 1972-2012: a retrospective cohort study. Arthritis Res Ther. 2017:19(1):278 Available from: https://arthritisresearch.biomedcentral.com/articles/10.1186/s13075-017-1479-6.
10. Gonzalez-Gay MA, Vazquez-Rodriguez TR, Lopez-Diaz MJ, Miranda-Filloy JA, Gonzalez-Juanatey C, Martin J, et al. Epidemiology of giant cell arteritis and polymyalgia rheumatica. Arthritis Rheum. 2009;61(10):1454-61.

11. Gonzalez-Gay MA, Barros S, Lopez-Diaz MJ, Garcia-Porrua C, SanchezAndrade A, Llorca J. Giant cell arteritis: disease patterns of clinical presentation in a series of 240 patients. Medicine (Baltimore). 2005:84(5): 269-76.

12. Liozon E, Herrmann F, Ly K, Robert PY, Loustaud V, Soria P, et al. Risk factors for visual loss in giant cell (temporal) arteritis: a prospective study of 174 patients. Am J Med. 2001;111(3):211-7.

13. Singh AG, Kermani TA, Crowson CS, Weyand CM, Matteson EL, Warrington KJ. Visual manifestations in giant cell arteritis: trend over 5 decades in a population-based cohort. J Rheumatol. 2015:42(2):309-15.

14. Miller NR. Visual manifestations of temporal arteritis. Rheum Dis Clin North Am. 2001:27(4):781-97 vi.

15. Sadda SR, Nee M, Miller NR, Biousse V, Newman NJ, Kouzis A. Clinical spectrum of posterior ischemic optic neuropathy. Am J Ophthalmol. 2001; 132(5):743-50.

16. Biousse V, Newman NJ. Ischemic Optic Neuropathies. N Engl J Med [Internet]. 2015;372(25):2428-36 Available from: http://www.nejm.org/doi/10. 1056/NEJMra1413352.

17. Hayreh SS. Posterior ischaemic optic neuropathy: clinical features, pathogenesis. and management. Eye (Lond). 2004;18(11):1188-206.

18. Lee AG, Eggenberger ER, Kaufman DI, Manrique C. Optic nerve enhancement on magnetic resonance imaging in arteritic ischemic optic neuropathy. J Neuroophthalmol. 1999:19(4):235-7.

19. He M, Cestari D, Cunnane MB, Rizzo JF. The use of diffusion MRI in ischemic optic neuropathy and optic neuritis. Semin Ophthalmol. 2010;25(5-6):225-32.

20. Bhatt NP, Morales RE. Mathews MK. MRI findings in Post-operative Bilateral Posterior Ischemic Optic Neuropathy. Open J Ophthalmol. 2013;3:51-3.

21. Danesh-Meyer H, Savino PJ, Gamble GG. Poor prognosis of visual outcome after visual loss from giant cell arteritis. Ophthalmology. 2005;112(6):1098-103.

22. Liu GT, Glaser JS, Schatz NJ, Smith JL. Visual morbidity in giant cell arteritis. Clinical characteristics and prognosis for vision. Ophthalmology. 1994; 101(11):1779-85.

23. Aiello PD, Trautmann JC, McPhee TJ, Kunselman AR, Hunder GG. Visual Prognosis in Giant Cell Arteritis. Ophthalmology [Internet]. 1993;100(4):550-555. Available from: https://doi.org/10.1016/S0161-6420(93)31608-8.

Ready to submit your research? Choose BMC and benefit from

- fast, convenient online submission

- thorough peer review by experienced researchers in your field

- rapid publication on acceptance

- support for research data, including large and complex data types

- gold Open Access which fosters wider collaboration and increased citations

- maximum visibility for your research: over $100 \mathrm{M}$ website views per year

At BMC, research is always in progress.

Learn more biomedcentral.com/submission 